DOI: $10.22363 / 2313-1683-2019-16-2-279-282$

UDC 159.99

\title{
The How and Why of Creating the First Psi Chi Video
}

\author{
Nancy J. Karlin \\ University of Northern Colorado \\ McKee 16d, Campus Box 94, Greeley, CO 80639, United States of America
}

\begin{abstract}
In 1998, Psi Chi produced its first video, under the guidance of Vice President Nancy Karlin. This nine-minute video offers detailed information featuring leading psychologists like Albert Bandura, Michael Wertheimer. Here, Dr. Karlin describes the back-story on how she crafted this stillunique video, which has been translated into Russian and is often used for chapter induction ceremonies the past 20 years.

In English: https://www.youtube.com/watch?v=a8Y8m2qxhS4

In Russian: https://www.youtube.com/watch?v=1t63fKZ1OPY
\end{abstract}

Key words: Psi Chi; history of Psi Chi; first Psi Chi video

While serving as a Vice President on the Psi Chi Council from 1995-1999, I saw a need using video technology to reach the high caliber students served by this organization. Psi Chi has continually been recognized for the high-quality services provided to advisors and students within an ever-expanding list of institutions of higher learning. However, as experienced by others who focus efforts on providing services the programs created can go unrecognized by the very individuals the organization seeks to support. Like so many, especially student-centered organizations, timely changes toward a technical form of information dissemination had become necessary, which lead to the idea of the promotional video. With a general notion of format, I brought my idea to the Council. This group of volunteers heard my argument and provided with an outline of the project. The Council agreed to my request of $\$ 10000$ to produce $1000 \mathrm{VHS}$ copies of the end product.

As writer and producer, I began to sketch out key ideas I felt were necessary to convey to both current and potential members. Historical reference was important. Highlighting the accomplishments of the past along-side current efforts of Psi Chi without question had to lay the foundation for the project. Beyond historical elements, other key aspects within the video were broad promotion of the organization, goals of the organization (i.e., academic recognition, professional growth), along with emphasis on the potential

(C) Karlin N.J., 2019

This work is licensed under a Creative Commons Attribution 4.0 International License 
for increased educational experience through international, national, and regional conventions. I also felt it was important to convey aspects of membership; as well as, what active membership could mean. The video allowed for the dissemination of the fact that once a Psi Chi member, always a member. Various presenters discussed the requirements of membership and that Psi Chi has more chapters than any other organization in the world. Fortunately, highly respected individuals like Kay Wilson (Psi Chi Executive Officer), Rebecca Bell (Undergraduate student at the time), along with renowned researchers and academic scholars Michael Wertheimer, Christina Maslach, Stephen Davis, Albert Bandura, Slater Newman, and Harold Takooshian discussed the various aspects of membership. Psi Chi had gained distinction as an organization that promoted responsible members through national, regional, and chapter service projects. A fact that could not be overstepped because few student-centered organizations continue to see as many hours given to these types of projects as Psi Chi.

Looking at the impressive list of video participants there are those who might wonder how such a stellar group could be assembled. Like all Psi Chi regional vice-presidents, I was responsible for obtaining the invited speakers that year for Psi Chi's portion of the Rocky Mountain Psychological Association's (RMPA) annual convention. That particular year there was a joint Western Psychological Association/RMPA meeting, which was the last meeting of its kind. Efforts were made to obtain individuals recognized for their teaching, research, and/or service to psychology, who could play a role in the video as well as serve as an invited speaker. Individuals who took part in the video were extremely gracious and more than willing to be part of the project. Each of these highly touted persons took part with zero compensation. Most of these same individuals had gone through Psi Chi membership as a student and in most cases had served as President of the Organization, Regional Vice-President, Chapter Advisor, or as a Psi Chi invited conference speaker. Throughout the development and finalization of the project, I had the great fortune to have a number of discussions with the video participants. These are conversations I will cherish forever because many went beyond the project and included researcher specific professional discussions not found in textbooks.

These discussions stemmed from review of the script sent to those who would be in front of the camera. The script was based on guidelines of the organization and participant experiences with Psi Chi. My intent was to verify participants felt comfortable with what they would say in support of this outstanding organization. Some wording adjustments were requested along with suggestions for ways to improve transitions; however, no substantial changes were requested. Each suggestion came with the intent to improve the project as well as increase the overall impact on viewership.

An individual knowledgeable about video production employed by my academic institution agreed to help me film and edit the production. Using someone from my institution to facilitate production meant costs for the project would remain manageable on something the organization had never attempted. A written agreement was signed between the two of us where he was to receive full travel compensation and a per diem. The compensation included an assistant at the filming site so as to facilitate efficiency on the days of filming and as a support mechanism on his portion of the project. Several meetings occurred prior to the filming. These meetings included a thorough review of the script, project layout and appearance, information on the list of participating 
individuals, details about filming location and times, requirements for both my part and his part to complete the final project, information on arrival and departure to the filming location, and the final date all copies of the project would be provided to the National Office. During one of the meetings, we decided that it would be easier to provide a highquality copy of the project to Psi Chi, which would allow the National Office staff to have the copies made rather than incurring the expense of shipping 1000 copies from Colorado to Tennessee.

I made arrangements for the two-person video crew to attend the conference and the room where filming took place. Filming occurred over a two-day period with approximately ten hours of actual onsite production time. Voice overs and editing occurred at my academic institution and encompassed a great deal of effort to reach completion of the project. Ultimately, each chapter of Psi Chi received a copy of the video for use in recruiting and/or chapter inductions.

Since 1998, Psi Chi has changed but in many important ways has remained the same. Changes to the organization have occurred like Psi Chi having moved from being a national organization to an international organization. This change in structure and philosophy took place at a time when psychological research was also seeking an international format. As a result, Psi Chi changed its name to demonstrate this structure change (The International Honor Society in Psychology). Other supporting organizations have also changed their name (Association of Psychological Sciences) in an effort to give emphasis to a broader base. Another change involves the substantial increase in the number of awards and grants offered to its membership. To date, over $\$ 400000$ per year is offered to students, local chapters, and faculty members.

Even with these changes, the video remains relevant in expressing the organization's impressive goals along with key aspects of Psi Chi that have not changed. What has not changed is that Psi Chi seeks to support members who are honest, well-rounded, academic achievers, and community volunteers. Psi Chi's executive officers have and will continue to provide outstanding support and distinguished service to a membership that extends throughout the globe while also promoting excellence in the science and application of psychology. These central organizational aspects were emphasized in the 1998 video and are still true today.

\section{Article history:}

Received: 21 February 2019

Accepted: 15 April 2019

\section{For citation:}

Karlin, N.J. (2019). The How and Why of Creating the First Psi Chi Video. RUDN Journal of Psychology and Pedagogics, 16(2), 279-282. http://dx.doi.org/10.22363/2313-1683-2019-16-2279-282

\section{Bio Note}

Nancy J. Karlin, Ph.D., FGSA, is Professor at School of Psychological Sciences, University of Northern Colorado (Greeley, USA); Fellow, Gerontological Society of America; and Convention Coordinator, RMPA. She served as Vice President on the Psi Chi Council from 1995-1999. E-mail: nancy.karlin@unco.edu 


\title{
Как и почему создавалось первое видео о Psi Chi
}

\author{
Н.Дж. Кэрлин \\ Университет Северного Колорадо \\ Соединенные Штаты Америки, 80639, штат Колорадо, Грили, МсKее 16d, Сатриз Bох 94
}

В 1998 г. под руководством вице-президента Нэнси Кэрлин было выпущено первое видео o Psi Chi. Впервые в 9-минутном видео была представлена подробная информация о психологическом обществе и ведущих психологах, таких как Альберт Бандура и Майкл Вертгеймер. В нашем кратком репортаже представлены предыстория и история создания этого по-прежнему уникального видео, которое часто используется во время церемоний открытия отделений Psi Chi в течение последних 20 лет, и в том числе было переведено на русский язык.

Видео доступно по ссылкам: https://www.youtube.com/watch?v=a8Y8m2qxhS4 (на английском языке) и https://www.youtube.com/watch?v=1t63fKZ1OPY (на русском языке).

Ключевые слова: Psi Chi; Международное психологическое общество почета; история Psi Chi; первое видео о Psi Chi

\section{История статьи:}

Поступила в редакцию: 21 февраля 2019

Принята к печати: 15 апреля 2019

\section{Для цитирования:}

Karlin N.J. The How and Why of Creating the First Psi Chi Video (Как и почему создавалось первое видео о Psi Chi) // Вестник Российского университета дружбы народов. Серия: Психология и педагогика. 2019. Т. 16. № 2. С. 279-282. http://dx.doi.org/10.22363/23131683-2019-16-2-279-282

\section{Сведения об авторе:}

Кэрлин Нэнси Дже, Ph.D., FGSA, профессор психологии Университета Северного Колорадо (Грили, США); научный сотрудник, Геронтологическое общество Америки; координатор конвенций, RMPA. Вице-президент совета директоров Psi Chi c 1995 по 1999 г. E-mail: nancy.karlin@unco.edu 